Short Communication

\section{SOLUBILITY OF BENZENE, TOLUENE AND $m$-XYLENE IN VARIOUS BODY FLUIDS AND TISSUES OF RABBITS}

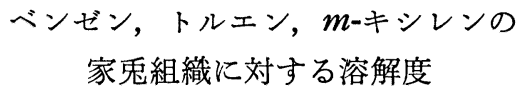

The dynamic distribution of any organic solvent vapor in the body is determined in large part by its solubility in the body tissues.1) Therefore, the solubility of the vapor in the blood and the body tissues are the primary determinant among the physicochemical factors influencing the absorption, distribution and elimination. The solubility of benzene, toluene and $m$-xylene in the blood were reported previously in this journal. ${ }^{2}$

This paper will cover the more extensive determinations of the solubility of these solvent vapors in various body fluids, tissues and tissue components of rabbits. The solubility was expressed in terms of partition coefficients, which was numerically requal to the Ostwald solubility coefficients.

\section{Methods}

The partition coefficients were determined according to the method of Larson et al. ${ }^{1)}$ with a little modification. Five $150 \mathrm{ml}$ glass bottles containing a known volume of blood or tissue homogenate were used as the test equilibration bottles. One $\mu 1$ of liquid solvent was injected into each of the bottles by a Hamilton microsyrings of $10 \mu 1$ capacity, Model 705. Then the bottles were stoppered with rubber and sealed with alminum leaves as quickly as possible.

The five control bottles were treated identically to the test bottles except that blood or tissue sample was not contained in them. Both test and control bottles were kept at $37^{\circ} \mathrm{C}$ in a thermo-regulated water bath with a shaker, and equilibration of the vapor between the sample and over-lying air was achieved. ${ }^{2,3)}$ After the equilibration for 2 to 6 hours, the concentration of the vapor in the gas phase was determined with a gas chromatograph equipped with a hydrogen flame ionization detector. One ml of the gas phase was drawn out by an airtight syringe through the stopper and then introduced into gas chromatograph, which was preconditioned as follows: carrier gas, $\mathrm{N}_{2}$ at $70 \mathrm{ml} / \mathrm{min}$; column, $2 \mathrm{~m}$ stainless steel tube packed with 10\% PEG 400 on Celite 545 ; column temperature, $70^{\circ} \mathrm{C}$; and injection temperature, $150^{\circ} \mathrm{C}$.
The resulted peak heights were employed ${ }^{4)}$ in the calculations described below.

Preparation of the sample: Whole blood was obtained from the carotid artery and pooled heparinized. Rabbit tissues excised from a freshly killed rabbits were stripped of capsular and vascular connective tissues and the quantity was determined. The tissues except the fat were then homogenized with a known volume of $0.9 \%$ saline. Ten $\mathrm{ml}$ of the tissue homogenates were put into the equilibration bottle and the weight of the sample was measured.

The substantial tissue volume $\left(V_{T}\right)$ of the sample was calculated as follows:

$$
V_{T}=10-\frac{V_{L} W_{2}}{W_{1}+p V_{L}}
$$

where, $W_{1}$ : weight of tissue which was homogenized, $V_{L}:$ volume of saline added, $p:$ specific gravity of saline, $W_{2}$ : weight of $10 \mathrm{ml}$ homogenate.

The adipose tissue was homogenized adding no saline. Then a small portion of the homogenate (approximately $1 \mathrm{~g}$ ), suspended in a known volume of saline, was equilibrated for the analysis. The volume of the fat sample was estimated from its average specific gravity of 0.908 .

Calculations: The tissue-air partition coefficient, $\lambda_{1}$, which is the ratio of the concentration of the vapor in the two phases, gas and tissue, was calculated by the following formula ${ }^{1,2)}$ :

$$
\lambda_{1}=\frac{h_{1} V_{B}-h_{2}\left(V_{S} \lambda_{S}+V_{B}-V_{S}-V_{T}\right)}{h_{2} V_{T}}
$$

where, $h_{1}, h_{2}$ : peak height obtained from $1 \mathrm{ml}$ of gas phase in the control $\left(h_{1}\right)$ or the test bottle $\left(h_{2}\right)$, $V_{B}$ : volume of bottle, $V_{S}, V_{T}$ : volume of saline $\left(V_{S}\right)$ or test material $\left(V_{T}\right), \lambda_{S}$ : solubility coefficient of solvent vapor for saline.

The tissue-blood partition coefficient, $\lambda_{2}$, was calculated according to the following formula:

$$
\lambda_{2}=\begin{aligned}
& \text { tissue-air partition coefficient } \\
& \text { blood-air partition coefficient }
\end{aligned}
$$

\section{Results}

The partition coefficients of benzene, toluene and $m$-xylene for blood and tissue homogenates of rabbits at $37^{\circ} \mathrm{C}$ are shown in Table 1 . Corresponding values for human fat, triolein, lecithin and cholesterol are included for comparison.

\section{Discussion}

The partition coefficients of the three solvent vapors for fat were almost $50-100$ times as high as in the other tissues as shown in Table 1 .

The tissue-blood partition coefficients for the tissues other than the fat were almost in the range of 1 to 3 .

Because of high vapor solubility in the fat tissue, 
Table 1. Partition coefficients of benzene, toluene and $m$-xylene for body fluids, tissue homogenates and organic materials.

\begin{tabular}{|c|c|c|c|c|c|c|c|}
\hline & & \multicolumn{2}{|c|}{ Benzene } & \multicolumn{2}{|c|}{ Toluene } & \multicolumn{2}{|c|}{ m-Xylene } \\
\hline & & $m$ & 8 & $\mathbf{m}$ & $B$ & m & $\mathbf{s}$ \\
\hline \multirow[t]{2}{*}{$A$} & Blood & 10.70 & 1.35 & 16.99 & 2.62 & 37.36 & 6.53 \\
\hline & Plasma & 5.49 & 0.33 & 10.41 & 1.25 & 20.71 & 3.06 \\
\hline \multirow{8}{*}{ B } & Liver & 1.61 & 0.18 & 2.58 & 0.69 & 3.01 & 0.85 \\
\hline & K1dney & 1.13 & 0.28 & 1.54 & 0.36 & 1.65 & 0.47 \\
\hline & Brain, whole & 1.93 & 0.50 & 3.06 & 0.75 & 3.31 & 1.35 \\
\hline & Lung & 1.25 & 0.31 & 1.92 & 0.18 & 2.09 & 0.51 \\
\hline & Heart & 1.44 & 0.38 & 2.10 & 0.88 & 2.08 & 0.88 \\
\hline & Muscle, fenoral & 1.08 & 0.17 & 1.18 & 0.18 & 1.62 & 0.43 \\
\hline & Bone marrow & 16.18 & 2.45 & 35.43 & 8.45 & 41.67 & 4.68 \\
\hline & Fat, retroperitoneal & 58.53 & 11.87 & 113.16 & 26.68 & 145.79 & 40.07 \\
\hline \multirow{5}{*}{$c$} & Lecithin, from egB & 196.42 & 9.30 & 608.76 & 21.19 & 1799.78 & 54.28 \\
\hline & Triolein & 535.68 & 31.14 & 1726.47 & 105.83 & 4621.37 & 205.32 \\
\hline & Cholesterol & 20.95 & 0.85 & 53.00 & 2.12 & 118.19 & 6.01 \\
\hline & Cholesterol oleate & 83.65 & 4.49 & 266.04 & 14.75 & 820.94 & 50.68 \\
\hline & Human fat, peritoneal & 406.22 & 10.10 & 1296.06 & 91.52 & 3604.67 & 198.74 \\
\hline
\end{tabular}

A:Fluid-air partition coefficients. The fioures are means(m) and standara deviations (s) of 5 rabivits.

B:Tissue-blood partition coefficients, which are expressed as

tissue-air partition coefficient. The fioures are means and standard deviations of 5 rabits.

C:Material-air partition coefficients. The figures are means and standard deviations of 5 determinations. Whe huran fat material was obtained from 7 year old boy who was died of acute leukenia.

small changes in fat content in any tissue may be predicted to alter the value of partition coefficient for that tissue. Furthermore, by comparing the solubility in lecithin, triolein and cholesterol, it is evident that the fat content in the form of neutral fat is a primary determinant for the level of solubility. This fact is demonstrated in the second highest value for the red bone marrow, the fat content of which was approximately $20 \%$ by volume, almost in the form of neutral fat. ${ }^{5)}$ Then it must be emphasized that the partition coefficients described here are only approximate values, since fat content in any tissue may vary as a result of several factors, including nutritional status of the organism. ${ }^{1)}$

Schrenk and his co-workers ${ }^{6)}$ detected approximately 20 times as much benzene in the bone marrow and peritoneal fat as in the blood and vital tissues such as liver and kidney of dogs exposed to benzene vapor. They also reported that the red blood cells contained benzene twice as much as that in the plasma. The partition coefficients of benzene shown in the Table 1 will present a logical explanation for these findings.

Because of the extremely high solubility of the solvent vapors in the fat and the relatively poor blood flow to fat compartment, adipose tissues may be expected to behave itself, in the uptake, distribution and excretion of the vapors in a living body, in somewhat a different manner from the other tissues.

In view of the features above described, it was possible to construct a three compartment mod$\mathrm{el}^{7)}$ for the transfer of organic solvent vapors in a biological system, which would offer an appropriate explanation for the three exponential decays $^{8}$ ) of benzene and toluene inhaled in man.

In summary, the tissueblood partition coefficients of benzene, toluene and $m$-xylene for various body fluids and tissues of rabbits were determined. The values of all three solvent vapors for the fat were extremely higher than the values for the other tissues except the bone marrow.

\section{References}

1) Larson, C.P. Jr., Eger, E. I. (II) and Severinghaus, J. W.: The solubility of halothane in blood and tissue homogenates, Anesthesiology, 23: 349-355, 1962.

2) Sato, A., Fujiwara, Y. and Hirosawa, K.: Solubility of benzene, toluene and $m$-xylene in blood (in Japanese), Jap. J. Ind. Health, 14: 3-8, 1972.

3) Sato, A.: Gas chromatographic determination of benzene, toluene and $m$-xylene in blood by equilibration method (in Japanese), Jap. J. Ind. Health, 13: 173-179, 1971.

4) Sato, A.: Gas chromatographic determination of benzene and toluene in expired air, Med. J. Shinshu Univ., 13: 167-173, 1968.

5) Unpublished data.

6) Schrenk, H. H., Yant, W. P., Pearce, S. J., Patty, F. A. and Sayers, R. R.: Absorption, distribution and elimination of benzene by body tissues and fluids of dogs exposed to benzene vapor, J. Industr. Hyg. Toxicol., 23: 20-34, 1941.

7) Sato, A., Nakajima, T., Fujiwara, Y., and Hirosawa, K.: Pharmacokinetics of benzene and toluene, Int. Arch. Arbeitsmed. (to be published).

8) Sato, A. and Fujiwara, Y.: Elimination of inhaled benzene and toluene in man, Jap. J. Ind. Health, 14: 224-225, 1972.

Akio SATo, Yukiko Fujiwara and Tamie NAKajima

Department of Hygiene, Faculty of Medicine, Shinshu University

Received for publication September 10, 1973

佐藤章夫, 藤原幸子, 中島民江

信州大学医学部衛生学教室 